\title{
Fish movement in an Atlantic Forest stream
}

\author{
Rosana Mazzoni ${ }^{1}$, Miriam Plaza Pinto ${ }^{2}$, Ricardo Iglesias-Rios ${ }^{3}$ and Raquel Costa ${ }^{1,4}$
}

Given the importance of fish movement to the dynamics and maintenance of stream dwelling fish communities from the Atlantic Forest, we analysed patterns of fish movement in a coastal stream from Southeastern Brazil, using mark-recapture technique. Displacement distance of each species were presented and discussed considering seasonal (rainy and dry) and body size patterns. We marked 10 species along the stream and recaptured $440(34.6 \%)$ of the 1,270 marked fishes. The species with significant number of upstream moving individuals were Astyanax janeiroensis, Characidium interruptum, Astyanax hastatus, Parotocinclus maculicauda and Awaous tajasica. Only Pimelodella lateristriga presented significant differences between resident and moving individuals. Characidium interruptum and A. tajasica demonstrated greater downstream and upstream movement, respectively, moving up to $2,100 \mathrm{~m}$. Even after controlling for species identity we found no significant correlation between fish length and individual displacement distance. Fishes moved longer distances during the rainy season, in accordance to the breeding season. Patterns of fish movement were in agreement to life-history traits of many of the studied species and can be reflecting specific behaviour and morphologies.

Keywords: Coastal stream, Migration, Reproduction, Stream dwelling fish.

Considerando-se a importância do movimento de peixes para a dinâmica e manutenção das comunidades de peixes de riachos da mata Atlântica, nós analisamos os padrões de movimento de peixes de um riacho costeiro do sudeste do Brasil, usando a técnica da marcação e recaptura. Avaliamos a distância do deslocamento de cada espécie e também se os padrões de movimento apresentavam alguma relação com a estação do ano (chuva e seca) e o tamanho do corpo. Marcamos 10 espécies ao longo do riacho e recapturamos 400 (34.6\%) dos 1.270 peixes marcados. As espécies com número significativo de indivíduos se movendo para cima foram Astyanax janeiroensis, Characidium interruptum, Astyanax hastatus, Parotocinclus maculicauda e Awaous tajasica. Apenas Pimelodella lateristriga apresentou diferenças significativas entre os indivíduos residentes e em movimento. Characidium interruptum e A. tajasica foram as espécies com maior movimento tanto para baixo como para cima, respectivamente, se movendo até mais de $2.100 \mathrm{~m}$. Mesmo após controlar a identidade das espécies, não registramos correlação significativa entre o comprimento e a distância individual do deslocamento. Registramos maiores densidades de peixes se movendo para montante durante a época de chuvas, em coincidência com a estação reprodutiva. Os padrões de movimento registrados estão de acordo com os componentes da história de vida de várias das espécies estudadas, e podem estar refletindo componentes morfológicos e comportamentais específicos.

Palavras-chave: Migração, Peixes de riacho, Riacho costeiro, Reprodução.

\section{Introduction}

An individual movement can be defined as a change in position in a certain time interval. It is a consequence of processes acting at multiple spatial and temporal scales (Nathan et al., 2008). Movement is essential for several ecological processes, such as population or individual dispersion, metapopulation dynamics, local species richness, local and regional population dynamics as well as local fitness opportunities (Gilliam, Fraser, 2001; Mazzoni et al., 2015). Given the importance of Atlantic Forest coastal streams as biodiversity hotspots, and the role of fish movement to the ecosystem functioning (Schlosser, 1995), it is fundamental to understand the patterns and mechanisms of fish movement in these environments.

\footnotetext{
${ }^{1}$ Laboratório de Ecologia de Peixes, Departamento de Ecologia, Instituto de Biologia Roberto Alcantara Gomes, Universidade do Estado do Rio de Janeiro. Av. São Francisco Xavier 524, 20550-013 Rio de Janeiro, RJ, Brazil. mazzoni@uerj.br, @ohttps://orcid.org/00000001-8780-7779 (corresponding author)

${ }^{2}$ Centro de Biociências, Departamento de Ecologia, Campus Universitário Lagoa Nova, Universidade Federal do Rio Grande do Norte, 59078-900 Natal, RN, Brazil. E-mail: miriamplazapinto@yahoo.com.br

${ }^{3}$ Universidade Federal do Rio de Janeiro, Instituto de Biologia, Departamento de Ecologia, C.P. 68.020, 21941-590 Rio de Janeiro, RJ, Brazil.nalaluzr@gmail.com

${ }^{4}$ Programa de Pós-graduação em Ecologia e Evolução, Instituto de Biologia Roberto Alcantara Gomes, Universidade do Estado do Rio de Janeiro, 20551-030, Rio de Janeiro RJ, Brazil. raquelcs.bio@yahoo.com
} 
Stream fish movements can be performed through a short or a long distance. Short distance movements (local) are generally related to changes in resources availability (Albanese et al., 2004), like food or refuge (Gowan, Fausch, 2002; Gowan, 2007), predation risk (Roberts, Angermeier, 2007), or to abiotic conditions like salinity, stream flow (Branco et al., 2017; Romão et al., 2017), and dissolved oxygen (Branco et al., 2016). Local movements can also be related to ontogeny, being an important life-history trait for several species (Winemiller, Jepsen, 1998). Long distance movements (regional) are related mainly to reproduction, colonization of available habitats (Adams, Warren, 2005) as well as genetic exchange between populations (Henriques et al., 2010). In order to increase the offspring survival and to avoid intraspecific competition, some species displace kilometres and occupy specific habitats, with higher productivity and lower predator density (Schulz, Leal, 2012). Long spawning migration can occur in some fish groups, such as salmonids and large migratory fishes from Amazon and Paraná basins (Goulding, 1980; Winemiller, Jepsen, 1998; Antonio et al., 2007; Fernadez et al., 2007; Pesoa, Schulz, 2010; Tejerina-Garro, Mérona, 2010). Fish movements in streams can also be important for the fish community stability (Martin-Smith et al., 1999).

According to the Restricted Movement Paradigm postulated by Gerking (1959), adult stream-dwelling fishes have a restricted home range, so they are sedentary and spend their life at restricted stream reaches $(20-50$ $\mathrm{m})$. The scientific community accepted this idea and some studies corroborated it (e.g. Rodríguez, 2002; Petty, Grossman, 2004). Nonetheless, it also received several criticisms (Riley et al., 1992; Young, 1994; Gowan, Fausch, 1996; Roberts et al., 2008; Breen et al., 2009). Gowan et al. (1994) found, for example, that streamdwelling fish can move long distances when conditions in their present foraging location become sub-optimal relative to conditions at other locations in the same reach. Movement was shown to be required for reproduction, dispersing to new habitats, or avoiding adverse habitat or resource conditions (Bryant et al., 2009; Flecker et al., 2010; Young, 2011).

Since these studies were done (e.g. Gowan et al., 1994; Bryant et al., 2009; Flecker et al., 2010; Young, 2011), the number of studies on this topic has increased, however mainly in temperate regions (e.g. Schlosser, 1991). Movement frequency seems to be higher than expected (Gowan et al., 1994; Smithson, Johnston, 1999; Crook, 2004; Roberts et al., 2008; Breen et al., 2009), and stream fish populations are not completely sedentary. There are also some intra-population behaviour differences in which some individuals are sedentary, some are mobile, and others alternate between both behaviours (Knaepkens et al., 2005). Such variability contributes to colonization and maintenance of the gene flow (Hughes et al., 2009). Previous studies in tropical streams (e.g. Mazzoni, Iglesias-Rios, 2012; Mazzoni et $a l ., 2015)$ revealed that fishes move longer distances than that mentioned by Gerking (1959). Mazzoni, IglesiasRios (2012) registered fish movement in a tropical stream and suggested that they were mainly motivated by reproduction. Fish movements could also be related to invasion and colonization process, and this was already shown in a tropical stream (Mazzoni et al., 2015).

Stream fishes change dramatically along ontogeny. Associated with these changes they exhibit complex life cycle and habitat-use patterns, with these latter being mediated by migratory processes (Schlosser, 1995). Several studies and models have been developed in temperate regions inferring about fish movement, predominantly on trout and salmon reproductive migrations in North America and in Europe (e.g. Quinn, Myers, 2004; Cooke et al., 2011). In contrast, there are few studies about both long and short distance fish movement and home range in tropical streams (e.g. Mazzoni, Iglesias-Rios, 2012; Mazzoni et al., 2015). The available studies for Neotropical region described migratory routes in large rivers of Amazon and Paraná basins (e.g. Goulding, 1980; Alves et al., 2007; Antonio et al., 2007; Fernadez et al., 2007; Tejerina-Garro, Mérona, 2010).

The knowledge about these movements in a region as diverse as the Neotropical is essential to understand fish community dynamics over local diversity as well as the anthropic effects of drainage fragmentation and the consequent limitation of fish movement. Following this, we investigated the longitudinal movement patterns of fishes in a Neotropical stream using mark-recapture technique. We tested the between-species differences in frequency and displacement distance. In addition, considering that reproductive traits are expected to affect fish movement (Mazzoni, Iglesias-Rios, 2012), the relationship between movement and season (rainy and dry) and body size were also investigated.

\section{Material and Methods}

Study area. Fish movement was investigated in the Ubatiba fluvial system, located in the Northeastern portion of the Rio de Janeiro State (Fig. 1). The Ubatiba system is a small costal microbasin approximately $15 \mathrm{~km}$ long, and drain a low altitude mountain hill $(<500$ m.a.s.l.) in the east slope of Serra do Mar mountain chain. It flows into the Maricá lagoon brackish system in a sand dune area. Secondary Atlantic forest predominates at its headwaters whereas some deforested areas are common in the middle and lower stream. Water level is regulated by rainfall and run-off. Rainy season is concentrated from November to January, but stochastic spates are common all over the year. The Ubatiba stream ichthyofauna is composed of 22 species (Mazzoni, Lobón-Cerviá, 2000; Mazzoni et al., 2006), arranged in 14 families and/or subfamilies. 


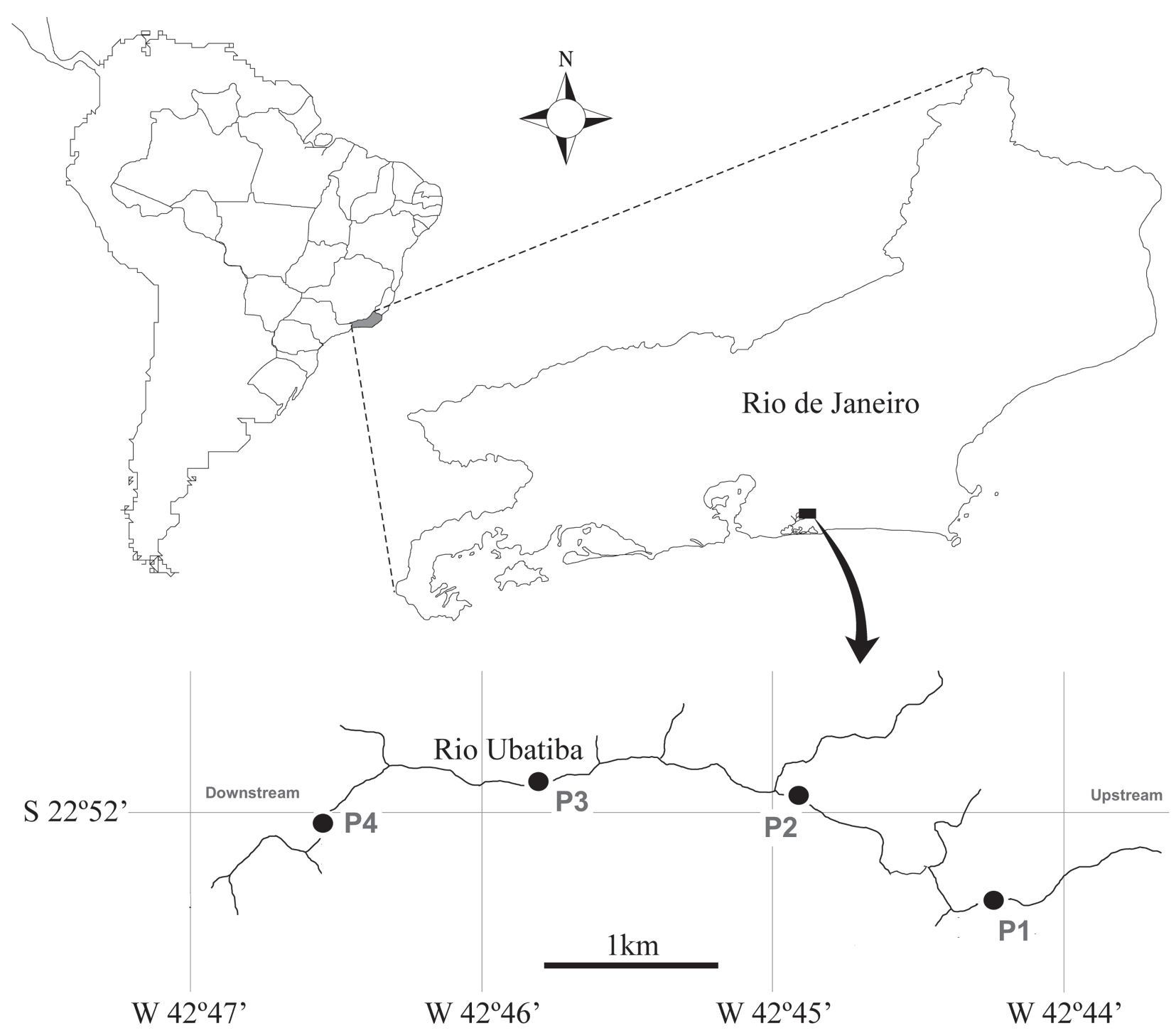

Fig. 1. Ubatiba stream system showing all the four sampling sites. $P 1$ is the most upstream site and $P 4$ is the most downstream site.

Sampling and data analysis. We sampled four sites $500 \mathrm{~m}$ apart from each other throughout the Ubatiba stream: site P1 $\left(22^{\circ} 51^{\prime} 53.3^{\prime \prime} \mathrm{S}\right.$ and $\left.42^{\circ} 45^{\prime} 77^{\prime \prime} \mathrm{W}\right)$, site P2 ( $21^{\circ} 52^{\prime} 47.7^{\prime \prime} \mathrm{S}$ and $\left.42^{\circ} 45^{\prime} 28.4^{\prime \prime} \mathrm{W}\right)$, site P3 (22 $51^{\prime} 55.2^{\prime \prime} \mathrm{S}$ and $\left.42^{\circ} 46^{\prime} 23.5^{\prime \prime} \mathrm{W}\right)$ and site P4 (22 $52^{\prime} 03.4^{\prime \prime} \mathrm{S}$ and $\left.42^{\circ} 47^{\prime} 55.4^{\prime \prime} \mathrm{W}\right)$. Site P1 was separated by all of the other sites (P2, P3 and P4) by a $3 \mathrm{~m}$ high waterfall that represent a structural barrier for some but not all Ubatiba stream species (Mazzoni, Lobón-Cervià, 2000). Each sampling site comprised a $150 \mathrm{~m}$ long stream reach subdivided into three $50 \mathrm{~m}$ stretches numbered according to its position in the whole sampling area (Fig. 2) and encompassed all meso-habitats present along the longitudinal gradient of the stream. Samplings were done from June 2011 to April 2012. We did two marking events, June 2011 and in November 2011, and seven recaptures events, July, August, September and November 2011 and January, February and April 2012. During the second marking event (November 2011) we also quantified recaptured fishes (the ones with elastomer marks).
At each sampling event the two extreme points of each sampling site were closed with nets (mesh size $0.5 \mathrm{~cm}$ ) to avoid any fish escape during sampling. Fish were collected by electrofishing (1,000 W, $220 \mathrm{~V}, 2-4 \mathrm{~A})$, applying the Removal Method (Zippin, 1958). Removals were done until no specimen was found in the study site. Sampled fish were placed in floating cages and kept alive away from the effect of electricity. After that, all sampled individuals were marked with colored elastomer (Visible Implant Elastomers - Northwest Marine Technology, Inc.) at the base of the dorsal fin, with a unique color for each site and then returned alive at the middle point of the sampling site. Different elastomer colours were used according to the following: first marking event (July 2011) - orange at site P1, red at site P2, green at site P3 and blue at site P4; second marking event (November 2011) - white at site P1, purple at site P2, black at site P3 and pink at site P4 (Fig. 1). Fishes were marked at the central stretch of each site. 


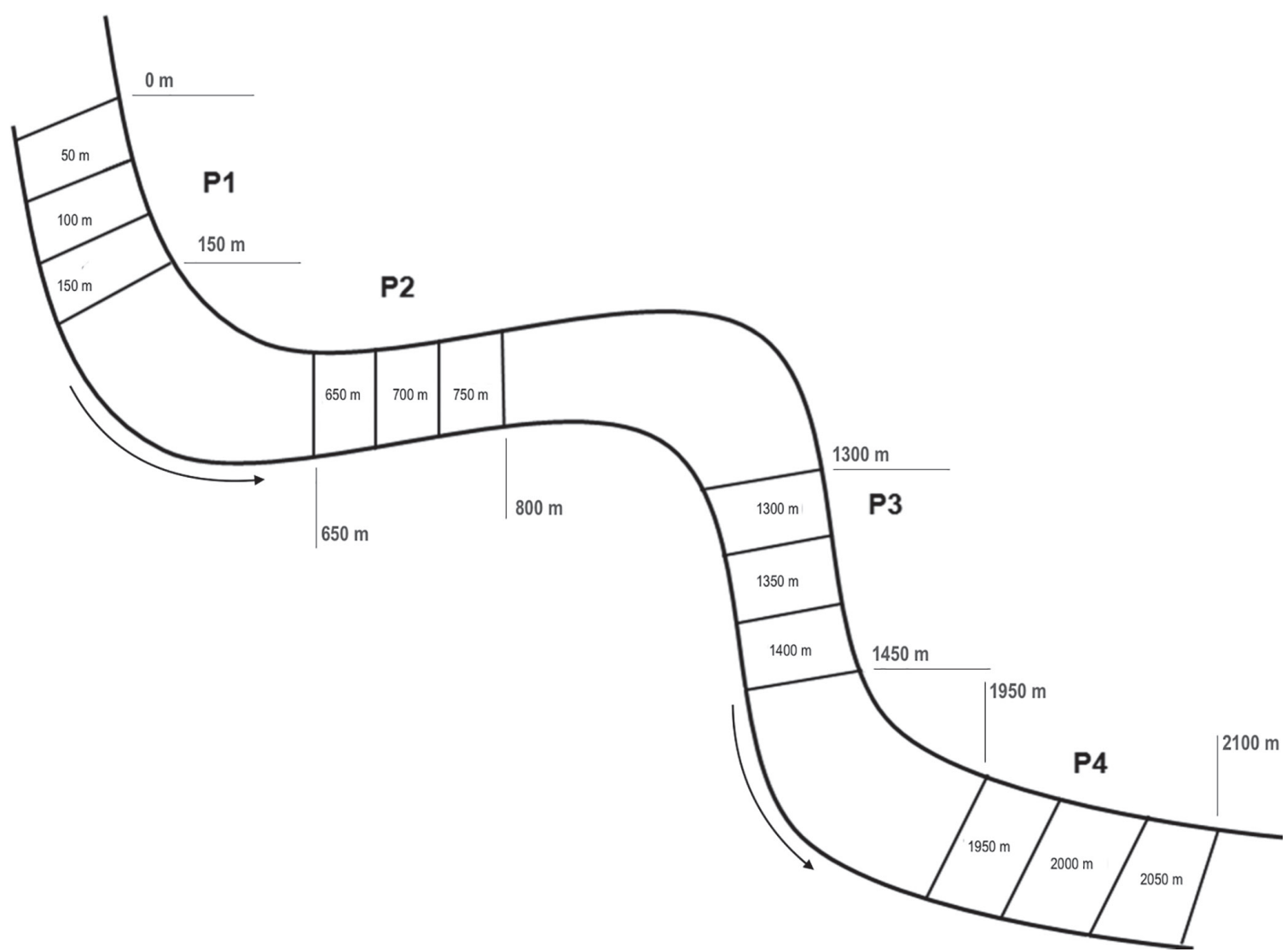

Fig. 2. Schematic representation of the study area. Numbers were designated according to the distance of each stretch to the first stretch $(0 \mathrm{~m})$. Arrows indicate the water flow.

Although the Ubatiba stream ichthyofauna is composed of 22 species (Mazzoni, Lobón-Cervià, 2000; Mazzoni et al., 2006), only 10 were studied. The remaining 12 species were not included due to their low abundance or small size $($ e.g. Poeciliidae $<3.0 \mathrm{~cm})$, which hindered their marking. We marked all individuals larger than 3.0 $\mathrm{cm}$, of each studied species. The studied species were: Astyanax hastatus Myers, 1928 (UERJ 2247), Astyanax janeiroensis Eigenmann, 1908 (UERJ 2249), Awaous tajasica (Lichtenstein, 1822) (UERJ 2244), Characidium interruptum Pellegrin, 1909 (UERJ 2253), Geophagus brasiliensis (Quoy and Gaimard, 1824) (UERJ 2252), Hoplias malabaricus (Bloch, 1794) (UERJ 2248), Hypostomus punctatus Valenciennes, 1840 (UERJ 2245), Parotocinclus maculicauda (Steindachner, 1877) (UERJ 2250), Pimelodella lateristriga (Lichtenstein, 1823) (UERJ 2246) and Rineloricaria sp. (UERJ 2254). Voucher specimens were deposited in the Ichthyological collection from Universidade do Estado do Rio de Janeiro (UERJ), Rio de Janeiro State, Brazil.

Distance moved by each individual was measured by the difference between the final (recapture) and original (mark) position along the study area. Each individual recapture was considered an observation event in our data set. These differences could be: zero $(=0)$, when we assume that fish did not move since it was recaptured in the original marking site, so, were considered as resident individuals; positive values ( $>$ zero) meaning that fish moved to an upstream position; and negative values $(<$ zero), meaning that fish moved to a downstream position. Movements were classified as short $(<50 \mathrm{~m})$ or long $(450$ to $1,600 \mathrm{~m})$.

In order to test the efficiency of the Successive Removal Method - SRM (Zippin, 1958), and consequently the number of captured fishes, capture data for single species and dates were tested for homogeneity of catchability (HC) between successive removals and for failure conditions (FC). These are metrics ( $\mathrm{HC}$ and FC) are necessary to be attended in order to validate the SRM. The SRM was applied in a Basic Program developed by and available at (LobónCerviá, 1991). More detailed information about sampling methodology is available at Mazzoni et al. (2000). To test whether the number of fish recaptured, outside the marking site, differed between each (June and November) marking event, we used the t-test to analyse the mean recapture percentages for each marking event. We used chi-square test to infer whether the observed frequency of moving and resident individuals differed significantly, for each species. Seasonal differences, considering rainy and dry seasons, in the distance moved by fishes were tested using a MannWhitney test. We used Spearman correlation analysis to evaluate the relationship between fish size and movement distance of each single species separately. 


\section{Results}

We marked 691 fishes in the first marking event (June 2011) and 579 in the second marking event (November 2011) summing 1,270 marked fishes. The number of marked and recaptured fish, of each species and sampling month, is presented (Tab. 1). Among the 440 recaptured fish, $261(59 \%)$ were recaptured out of the marking site. The remaining 179 fishes were recaptured at the same marking site. We assume that the fish recaptured at the same marking site did not move, since our methodology does not allow detecting return movement, if any. We recorded mean recapture outside the marking site of $9.7 \%$ and $11.1 \%$ for the first and second marking events, respectively, without significant differences of recaptures of moving fish of both marking events ( $\mathrm{t}$-value $=-0.32, p=0.75$ ).

Tab. 1. Number of marked (June and November / 2011) and recaptured (July, August, September and November / 2011 and January, February and April / 2012) fish, of the ten studied species from Ubatiba stream system.

\begin{tabular}{|c|c|c|c|c|c|c|c|c|c|}
\hline & \multicolumn{2}{|c|}{ Marking Events } & \multicolumn{7}{|c|}{ Recapture Events } \\
\hline & $\begin{array}{l}\text { June } \\
2011 \\
\end{array}$ & $\begin{array}{c}\text { November } \\
2011\end{array}$ & $\begin{array}{l}\text { July } \\
2011\end{array}$ & $\begin{array}{c}\text { August } \\
2011 \\
\end{array}$ & $\begin{array}{c}\text { September } \\
2011\end{array}$ & $\begin{array}{c}\text { November } \\
2011\end{array}$ & $\begin{array}{c}\text { January } \\
2012 \\
\end{array}$ & $\begin{array}{c}\text { February } \\
2012 \\
\end{array}$ & $\begin{array}{l}\text { April } \\
2012 \\
\end{array}$ \\
\hline Astyanax janeiroensis & 36 & 20 & 2 & 1 & 9 & 16 & 15 & 3 & 1 \\
\hline Astyanax hastatus & 38 & 94 & 0 & 0 & 2 & 10 & 10 & 1 & 2 \\
\hline Characidium interruptum & 65 & 32 & 0 & 3 & 9 & 10 & 11 & 9 & 1 \\
\hline Awaous tajasica & 119 & 75 & 22 & 28 & 25 & 5 & 25 & 6 & 3 \\
\hline Geophagus brasiliensis & 21 & 82 & 1 & 2 & 0 & 1 & 0 & 2 & 0 \\
\hline Hoplias malabaricus & 7 & 10 & 2 & 1 & 1 & 0 & 2 & 0 & 0 \\
\hline Hypostomus punctatus & 35 & 49 & 1 & 0 & 0 & 2 & 1 & 1 & 0 \\
\hline Parotocinclus maculicauda & 270 & 179 & 3 & 13 & 29 & 23 & 40 & 32 & 8 \\
\hline Pimelodella lateristriga & 98 & 37 & 7 & 4 & 9 & 14 & 5 & 4 & 0 \\
\hline \multirow[t]{2}{*}{ Rineloricaria sp. } & 2 & 1 & 0 & 0 & 0 & 2 & 1 & 0 & 0 \\
\hline & 691 & 579 & 38 & 52 & 84 & 83 & 110 & 58 & 15 \\
\hline
\end{tabular}

Five species showed a significantly higher number of individuals that performed movement along the studied stream reaches when compared to the resident species. The species with significant number of moving individuals (recaptured out of the marking site - Tab. 2) were $A$. janeiroensis $\left(87 \%\right.$ of moving fishes $-c^{2}=26.06 ;$ d.f. $=1 ; p<$ $0.05)$, C. interruptum ( $84 \%$ of moving fishes $-c^{2}=19.56 ;$ d.f. $=1 ; p<0.05), A$. hastatus ( $72 \%$ of moving fishes $-c^{2}=4.84$; d.f. $=1 ; p<0.05)$, P. maculicauda (59\% of moving fishes $-c^{2}$
$=5.30 ;$ d.f. $=1 ; p<0.05)$ and A. tajasica $(56 \%$ of moving fishes $-c^{2}=5.72 ;$ d.f. $=1 ; p<0.05$ ). All of these moving species presented large $(\geq 800 \mathrm{~m})$ upstream movement, with more than $50 \%$ of moving individuals. The species that moved the largest upstream distance were A. tajasica and P. maculicauda, they moved up to $2,100 \mathrm{~m}$ and $1,450 \mathrm{~m}$, respectively. Characidium interruptum and $A$. tajasica were the species with larger downstream movement, moving up to 2,100 m (Fig. 3, Tab. 3).

Tab. 2. Number of recaptured fish (Recaptures), number (Out of MS) and percentual (Out of MS - \%) of individuals recaptured out of the marking site and number (Resident) and percentual (Resident - \%) of individuals recaptured at the same marking site at Ubatiba stream, Southeast, Brazil.

\begin{tabular}{|c|c|c|c|c|c|}
\hline & Recaptures & Out of MS & Out of MS - \% & Resident & Resident $-\%$ \\
\hline \multicolumn{6}{|l|}{ CHARACIFORMES } \\
\hline Astyanax janeiroensis & 47 & 41 & 87 & 6 & 13 \\
\hline Astyanax hastatus & 25 & 18 & 72 & 7 & 28 \\
\hline Characidium interruptum & 43 & 36 & 84 & 7 & 16 \\
\hline Hoplias malabaricus & 6 & 3 & 50 & 3 & 50 \\
\hline \multicolumn{6}{|l|}{ PERCIFORMES } \\
\hline Awaous tajasica & 114 & 64 & 56 & 50 & 44 \\
\hline Geophagus brasiliensis & 6 & 1 & 17 & 5 & 83 \\
\hline \multicolumn{6}{|l|}{ SILURIFORMES } \\
\hline Hypostomus punctatus & 5 & 1 & 20 & 4 & 80 \\
\hline Parotocinclus maculicauda & 148 & 88 & 59 & 60 & 41 \\
\hline Pimelodella lateristriga & 43 & 8 & 19 & 35 & 81 \\
\hline Rineloricaria sp. & 3 & 1 & 33 & 2 & 67 \\
\hline
\end{tabular}




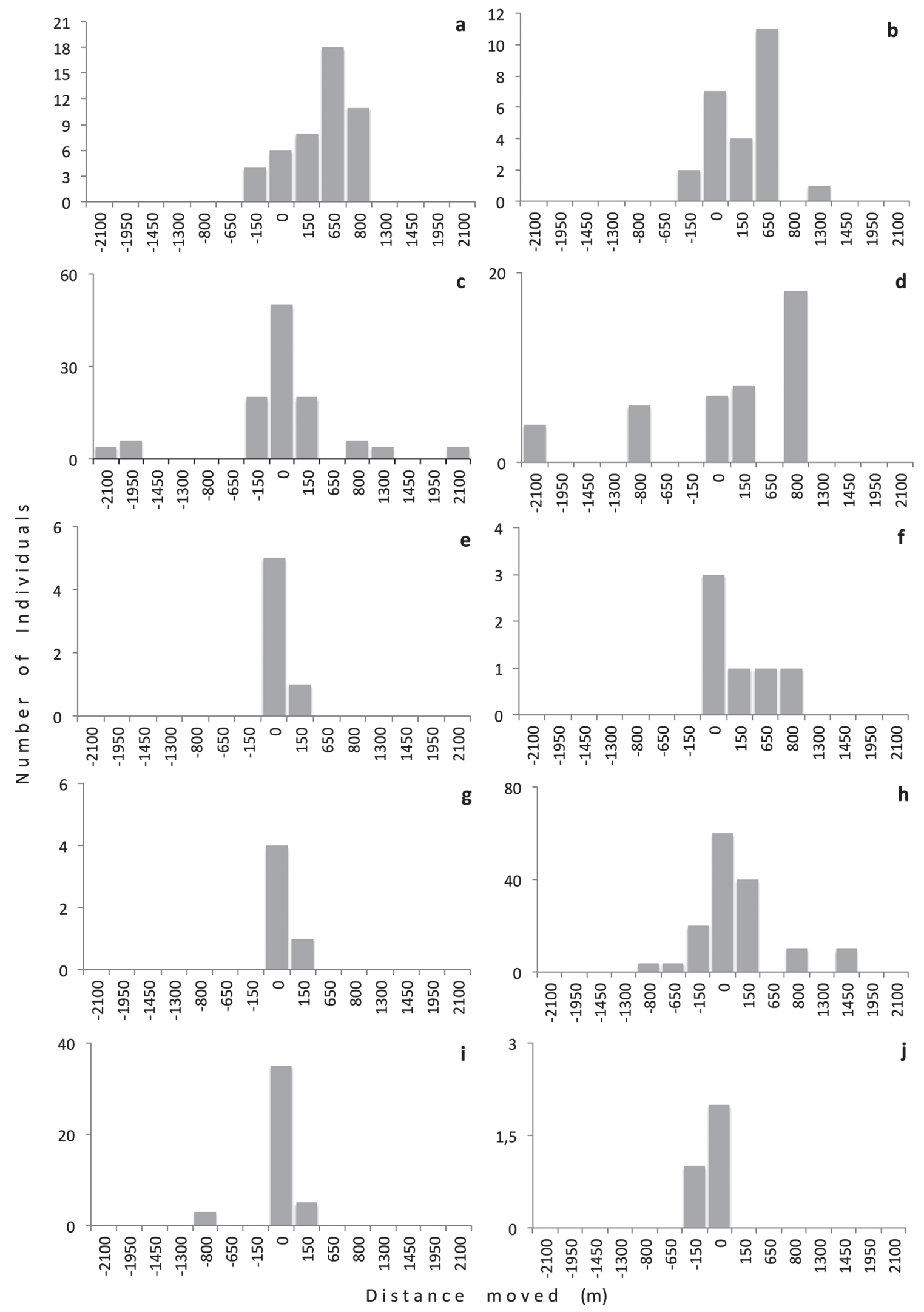

Fig. 3. Distance moved by fish species from Ubatiba stream. Zero means that the individuals did not move, negative and positive values means down- and upstream movements, respectively. a. Astyanax janeiroensis; b. Astyanax hastatus; c. Awaous tajasica; d. Characidium sp.; e. Geophagus brasiliensis; f. Hoplias malabaricus; g. Hypostomus punctatus; h. Parotocinclus maculicauda; i. Pimelodella lateristriga; j. Rineloriacaria sp. 
Tab. 3. Mean (M) and maximum (Max) values of upstream (Up) and downstream (Dw) distances in meters (m) moved by the studied species from Ubatiba stream, Southeast, Brazil.

\begin{tabular}{|c|c|c|c|c|}
\hline Species & M Up (m) & $\mathrm{M}$ Dw (m) & $\operatorname{Max} \mathrm{Up}(\mathrm{m})$ & Max Dw (m) \\
\hline Astyanax janeiroensis & $592 \pm 237$ & $150 \pm 0$ & 800 & 150 \\
\hline Astyanax hastatus & $566 \pm 286$ & $150 \pm 0$ & 1300 & 150 \\
\hline Characidium interruptum & $600 \pm 300$ & $1320 \pm 878$ & 800 & 2100 \\
\hline Hoplias malabaricus & $533 \pm 277$ & 0 & 800 & 0 \\
\hline Awaous tajasica & $629 \pm 669$ & $770 \pm 877$ & 2100 & 2100 \\
\hline Geophagus brasiliensis & $150 \pm 0$ & 0 & 150 & 0 \\
\hline Hypostomus punctatus & $150 \pm 0$ & 0 & 150 & 0 \\
\hline Parotocinclus maculicauda & $475 \pm 496$ & $314 \pm 263$ & 1450 & 800 \\
\hline Pimelodella lateristriga & $150 \pm 0$ & $800 \pm 0$ & 150 & 800 \\
\hline Rineloricaria sp. & 0 & $150 \pm 0$ & 0 & 150 \\
\hline
\end{tabular}

Exception for P. lateristriga, that presented significant number of resident individuals (recaptured at the marking site) $\left(81 \%-c^{2}=16.95 ;\right.$ d.f. $\left.=1 ; p<0.05\right)$, all the other species did not present significant differences between resident and moving individuals (Geophagus brasiliensis $-c^{2}=2.67 ;$ d.f. $=1 ; p>$ $0.05 ;$ H. malabaricus $-c^{2}=0 ;$ d.f. $=1 ; p>0.05 ;$ H. punctatus $-c^{2}=1.80 ;$ d.f. $=1 ; p>0.05$ and Rineloricaria sp. $-c^{2}=0.33$; d.f. $=1 ; p>0.05)$. Although no significant, all these last species presented large proportion of resident individuals (Tab. 2).

There was no correlation between fish standard length and distance moved for all species. Additional analyses were done controlling for species but no relationship between fish size and movement was detected (Fig. 4 and see also Tabs. S1-S3 - Available only as online supplementary file accessed with the online version of the article at http://www.scielo.br/ ni). We detected a marginally significant difference in the distance moved by the fishes between the rainy and dry seasons (Mann-Whitney $\mathrm{U}=20979.50 ; p=0.0744$ ) with a tendency of fishes moving longer distances during the rainy season (Fig. 5). Nonetheless, when we tested only for the upstream movement, individuals moved significantly longer distances during the rainy season (Mann-Whitney $\mathrm{U}=319.50 ; p=0.0138$ ).

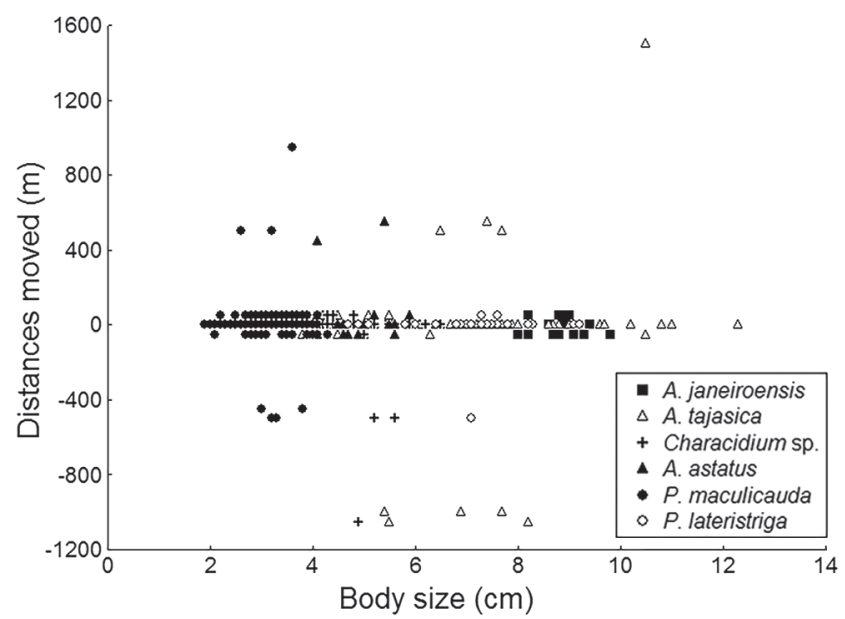

Fig. 4. Relationship between distance (m) moved and body size of the moving species from Ubatiba stream, Southeast, Brazil.

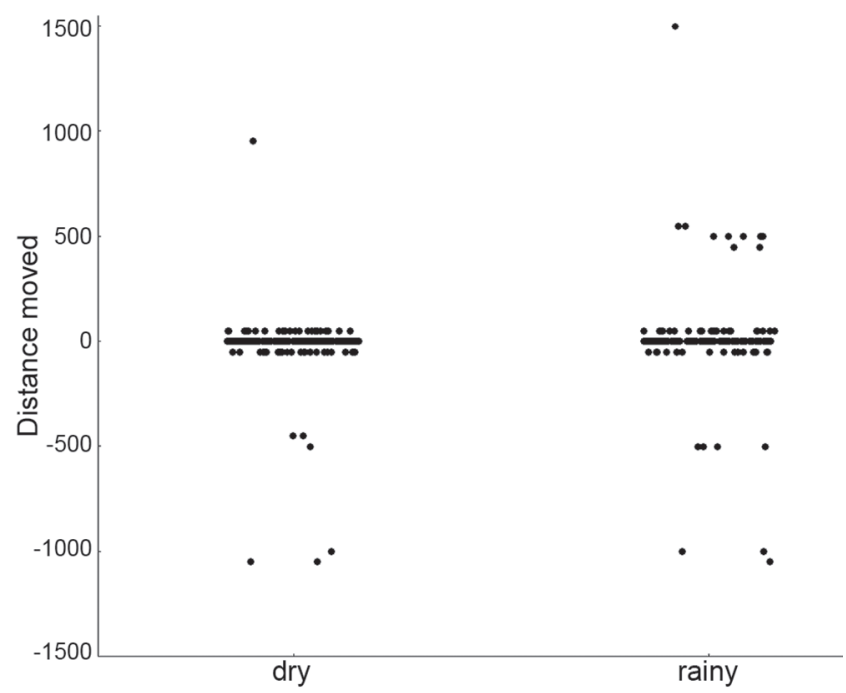

Fig. 5. Relationship between distance (m) moved by fishes and seasons (dry and rainy) of all moving species from Ubatiba stream, Southeast, Brazil.

\section{Discussion}

Fish recaptures decreased along sampling events and only $35 \%$ of all marked fish were recaptured. Tagging and photo-identification are among the most used tools for markrecapture studies. Photo-identification allows individual recognition of animal species based on natural marks and is an interesting alternative to other more stressful artificial tagging/marking techniques (Dala-Corte et al., 2016). Potential use of photo-identification for individual fish recognition has shown to be a feasible alternative to behaviour studies on freshwater fish. However, it was not efficient for the studied species because of a lack of marks allowing individual recognition.

Mortality, stress by handling and tag losses are among the causes of low recapture rates (Porto et al., 1999; Smithson, Johnston, 1999). Nonetheless, other studies have shown long durability and little (or minimal) degradation of the VIE implant tags in fish (Walsh, Winkelman, 2004; 
Josephson et al., 2008; Carvalho-Souza et al., 2010; Soula et al., 2012) as well as low mortality caused by tagging procedures (e.g. Riley et al., 1992). It is known that the characins and the other small species of the present study are much less resistant than the trout's of Riley et al. (1992) study, so that non-recaptures caused by mortality could not be completely discarded. However, our findings support the idea that low recapture rate could be a result of individuals dispersing outside the sampling area.

A total of 440 fishes were recaptured but only $112(25.45$ $\%)$ individuals moved out from their original marking site. Individuals of $G$. brasiliensis, $H$. punctatus, Rineloricaria sp. and $A$. janeiroensis were recaptured just near the marking site, moving through short distances. Fishes with restricted movement and small home-ranges face different challenges when compared to those with longer distance movement (Mazzoni, Iglesias-Rios, 2012). Cichlidae (G. brasiliensis) and Loricariidae (H. punctatus and Rineloricaria sp.) are territorial species, presenting parental care and nesting sites, so these reproductive traits constrain their movement (Marcucci et al., 2005; Hirschmann et al., 2011) and explain our findings during recapture experiments.

However, individuals of another Loricaridae species $(P$. maculicauda) were found up to $950 \mathrm{~m}$ above their marking site. Following the low moving ability of many Loricariidae species, the long distance moved by $P$. maculicauda in the present study was not expected. Many studies concerning Loricariidae (e.g. Hypostomus) behaviour have shown that they usually explore small stream stretches, mainly during the breeding season (Mazzoni, Caramaschi, 1995), suggesting that they did not move long distances from their territories. Nonetheless, the ability to move is a necessary prerogative for species to disperse and colonize new habitats (Hohausová et al., 2010). Following this, Mazzoni et al. (2015) have shown that P. maculicauda is an exotic species undergoing a colonization process in the same stream of this study. This may justify the larger movement pattern undertaken by the species and may explain the high number of moving individuals. However, it is important to note that little is known about the migratory behaviour of P. maculicauda in its original area of distribution and, therefore, it cannot be disregarded its migratory behaviour in coastal streams.

Both Characidae species found at Ubatiba stream (A. janeiroensis and A. hastatus) showed a high number of moving individuals. Astyanax janeiroensis moved a maximum of $800 \mathrm{~m}$ towards the high areas of the stream and A. hastatus moved at least $1,300 \mathrm{~m}$, also to upstream sites. Previous studies indicated that $A$. janeiroensis was able to move long distances in order to reach the upper sites in the stream headwaters. Mazzoni, Iglesias-Rios (2012) registered one individual moving at least $6,000 \mathrm{~m}$ beyond its marking site towards the upper stream reaches. Other indicative that the Astyanax species move to further upstream sites is the study carried out by Mazzoni et al. (2005), who found that young and adult individuals segregate along the stream as a consequence of reproductive movement. Reproductive segregation caused by fish movement to upstream areas in streams were also found to Mimagoniates microlepis (a Characiform species like Astyanax spp.) by Braga et al. (2013). The differences found in this study relative to the distance moved by $A$. janeiroensis could be attributed to the differences in the number of marked and recaptured individuals and the limitations imposed by the mark-recapture method. The sampling period could also be responsible for these differences as far as it has been registered, A. janeiroensis used to move upstream with reproductive motivations.

Awaous tajasica and Characidium sp. were not only the ones with the highest frequency of moving individuals but the ones showing the longest displacement pattern meaning that species with higher frequency of movement are not those with longer movements. These results indicate that species differ in their movement patterns, as already shown in many other studies (e.g. Skalski, Gilliam, 2000; Albanese et al., 2004; Roberts, Angermeier, 2007; Breen et al., 2009). The longest distance registered in this study was performed by an individual of $A$. tajasica that moved approximately $1,500 \mathrm{~m}$. Awaous tajasica is an estuarine Gobiidae species that normally move upstream into freshwater environments (Loebmann, Vieira, 2005). A lack of detailed studies about its biology and behaviour is a limiting factor to the complete understanding of the species motivation to move upstream in rivers and streams (e.g. Loebmann, Vieira, 2005). Nonetheless, it seems that $A$. tajasica is expanding its distribution in the Ubatiba stream. Six years ago 11 individuals were registered at site P4 (Mazzoni et al., 2006), but in the present study many individuals $(>50)$ were registered at all sampling sites. These observations along with observations about species' movement pattern (Mazzoni et al., 2015) suggest that $A$. tajasica was expanding its distribution area, colonizing new and more remote sites in the Ubatiba stream, moving short as well as long distances. Home-range is normally reflected by the distances moved by individuals in the population (Nathan, 2008), thus A. tajasica homeranges in Ubatiba stream seem to be large, however further studies in a regional scale should be developed to confirm this observation. These species can be moving beyond 1,500 $\mathrm{m}$, but another sampling design may be done to detect and confirm this.

Seasonal rain is an important factor structuring fish populations (Neiff, 1990). The beginning of rainy season acts as a trigger for fish reproduction (Bailly et al., 2008). During the rainy season all moving fishes moved longer distances towards the Ubatiba stream headwaters, which may be related to fish reproductive behaviour (Mazzoni et $a l ., 2005)$. We expected movement pattern to be positively related to body size (Haskell et al., 2002) reflecting age and the onset of sexual maturity, however, no significant relationship between body size (measured as standard length) and distance moved by individual fish was detected. The same lack of correlation was already registered by 
Mazzoni, Iglesias-Rios (2012) so, although it is necessary to run more extensive tests, the results we got so far suggest that first maturation and the beginning of sexual activity occurs very early among these stream-dwelling fish species (Mazzoni, Iglesias-Rios, 2002), explaining why all of the analysed individuals, independent of body size, were moving upstream with reproductive motivation.

In the present study, fish species from the Ubatiba stream showed different patterns of frequency and distance of movement. Nonetheless, no movement pattern related to taxonomic groups, for example, was registered. The Perciformes species ( $G$. brasiliensis and A. tajasica) presented opposite behaviour. Geophagus brasiliensis, following its territorial behaviour (Barreto, Volpato, 2006; Paraguassú et al., 2005; Kadry, Barreto, 2010) did not do large movements, while A. tajasica individuals, following its marine/estuarine invader behaviour (Minckley, Marsh, 2009), were registered very far from their marking sites. Siluriformes species ( $H$. punctatus, $P$. maculicauda, Rineloricaria sp. and P. lateristriga) also showed absence of taxonomic-related differences in the patterns of movement. Hypostomus punctatus, Rineloricaria sp. and P. lateristriga moved only small distances while $P$. maculicauda moved long distances. Individuals at the invasion front, such as the case of $P$. maculicauda, face some important differences compared to individuals in established populations, which may explain the taxonomic-related differences registered in this study as well as the difficulties faced to predict interspecific movement patterns. Also, among the four Characiformes species we registered taxonomic-related moving differences. Unfortunately very few information is available for these species in order to clarify which processes are driving the registered movement patterns.

All of these findings result in a general scheme of high differences in specific life history and morphological traits. These differences could also be determined by predator distribution, feeding resources, shelter availability, hydrological conditions and stream physiography and understanding these processes is fundamental to help in proposing conservation measures for coastal streams in the Atlantic Forest. Nonetheless, more studies directed to each individual species are necessary to clarify interspecific patterns and strategies of stream maintenance and occupation.

\section{Acknowledgments}

We thank Maja Kajin for reading and revising a previous version of this manuscript. This work was supported by Comissão de Aperfeiçoamento de Pessoal do Nível Superior - CAPES to Raquel Costa, Conselho Nacional de Desenvolvimento Científico e Tecnológico - CNPq (proc. 301621/2013-6), Fundação Carlos Chagas Filho de Apoio a Pesquisa do Estado do Rio de Janeiro - FAPERJ (proc. E-26/203.193/2015) and Programa Prociência/UERJ/Sr2 to Rosana Mazzoni.

\section{References}

Adams SB, Warren ML. Recolonization by warmwater fishes and crayfishes after severe drought in upper coastal Plain Hill streams. Trans Am Fish Soc. 2005; 134(5):1173-92.

Albanese B, Angermeier PL, Dorai-Raj S. Ecological correlates of fish movement in a network of Virginia streams. Can J Fish Aquat Sci. 2004; 61(6):857-69.

Alves CBM, Silva LGM, Godinho AL. Radiotelemetry of a female jaú, Zungaro jahu (Ihering, 1898) (Siluriformes: Pimelodidae), passed upstream of Funil Dam, rio Grande, Brazil. Neotrop Ichthyol. 2007; 5(2):229-32.

Antonio RR, Agostinho AA, Pelicice FM, Bailly D, Okada EK, Dias JHP. Blockage of migration routes by dam construction: can migratory fish find alternative routes? Neotrop Ichthyol. 2007; 5(2):177-84.

Bailly D, Agostinho AA, Suzuki HI. Influence of the flood regime on the reproduction of fish species with different reproductive strategies in the Cuiaba river, upper Pantanal, Brazil. River Res Appl. 2008; 24(9):1218-29.

Barreto RE, Volpato GL. Stress responses of the fish Nile tilapia subjected to electroshock and social stressors. Brazil J Med Biol Res. 2006; 39(12):1605-12.

Braga RR, Braga MR, Vitule JRS. Population structure and reproduction of Mimagoniates microlepis with a new hypothesis of ontogenetic migration: implications for stream fish conservation in the Neotropics. Environ Biol Fishes. 2013; 96(1):21-31.

Branco P, Santos JM, Amaral S, Romão F, Pinheiro AN, Ferreira MT. Potamodromous fish movements under multiple stressors: connectivity reduction and oxygen depletion. Sci. Tototal Environ. 2016; 572(1):520-25.

Branco P, Amaral SD, Ferreira MT, Santos JM. Do small barriers affect the movement of freshwater fish by increasing residency? Sci Total Environ. 2017; 581-582:486-94.

Breen MJ, Ruetz CR, Thompson KJ, Kohler SL. Movements of mottled sculpins (Cottus bairdii) in a Michigan stream: how restricted are they? Can J Fish Aquat Sci. 2009; 66(1):31-41.

Bryant MD, Lukey MD, McDonell JP, Gubernick RA, Aho RS. Seasonal movement of Dolly Varden and cutthroat trout with respect to stream discharge in a second-order stream in southeast Alaska. N Am J Fish Manage. 2009; 29(6):1728-42.

Carvalho-Souza GF, Browne-Ribeiro HC, Nascimento IA, Cerqueira RS, Tinôco MS. Avaliação do Implante Visível de Elastómero Fluorescente (VIFE) em Trichogaster trichopterus (Pallas, 1770) em cativeiro, incluindo informações sobre a técnica utilizada. Rev Bras Biocienc. 2010; 8(1):24-29.

Cooke SJ, Crossin GT, Hinch SG. Pacific salmon migration: completing the cycle. In: Farrell AP, editor. Energetics, interactions with the environment, lifestyles, and applications. London: Academic Press; 2011. (Encyclopedia of fish physiology: from genome to environment; vol 3)

Crook DA. Is the home range concept compatible with the movements of two species of lowland river fish? J Anim Ecol. 2004; 73(2):353-66. 
Dala-Corte RB, Moschetta JB, Becker FG. Photo-identification as a technique for recognition of individual fish: a test with the freshwater armored catfish Rineloricaria aequalicuspis Reis \& Cardoso, 2001 (Siluriformes: Loricariidae). Neotrop Ichthyol. 2016; 14(1):e150074 [10p.].

Fernandez DR, Agostinho AA, Bini LM, Pelicice FM. Diel variation in the ascent of fishes up an experimental fish ladder at Itaipu Reservoir: fish size, reproductive stage and taxonomic group influences. Neotrop Ichthyol. 2007; 5(2):215-22.

Flecker AS, McIntyre PB, Moore JW, Anderson JT, Taylor BW, Hall RO, Jr. Migratory fishes as material and process subsidies in riverine ecosystems. Am Fish Soc Symp. 2010; 73:559-92.

Gerking SD. The restricted movement of fish populations. Biol Rev Camb Philos Soc. 1959; 34(2):221-42.

Gilliam JF, Fraser DF. Movement in corridors: enhancement by predation threat, disturbance, and habitat structure. Ecology. 2001; 82(1):258-73.

Goulding M. The fishes and the forest: explorations in Amazonian Natural History. Berkeley: University of California Press, 1980.

Gowan C, Young MK, Fausch KD, Riley SC. Restricted movement in resident stream salmonids: a paradigm lost? Can J Fish Aquat Sci. 1994; 51(11):2626-37.

Gowan C. Short-term cues used by foraging trout in a California stream. Environ Biol Fish. 2007; 78(4):317-31.

Gowan C, Fausch KD. Long-term demographic responses of trout populations to habitat manipulations in six Colorado streams. Ecol Appl. 1996; 6(3):931-46.

Gowan C, Fausch KD. Why do foraging stream salmonids move during summer? Environ Biol Fish. 2002; 64(1-3):139-53.

Haskell JP, Ritchie ME, Olff $\mathrm{H}$. Fractal geometry predicts varying body size scaling relationships for mammal and bird home ranges. Nature. 2002; 418(6897):527-30.

Henriques R, Sousa V, Coelho MM. Migration patterns counteract seasonal isolation of Squalius torgalensis, a critically endangered freshwater fish inhabiting a typical Circum-Mediterranean small drainage. Conserv Genet. 2010; 11(5):1859-70.

Hirschmann A, Fialho CB, Grillo HCZ. Reprodução de Hemiancistrus punctulatus Cardoso and Malabarba, 1999 (Siluriformes: Loricariidae) no sistema da laguna dos Patos: uma espécie de ambiente lótico frente às alterações provocadas por represamentos. Neotrop Biol Conserv. 2011; 6(3):250-57.

Hohausová E, Lavoy RJ, Allen MS. Fish dispersal in a seasonal wetland: influence of anthropogenic structures. Mar Freshwater Res. 2010; 61(6):682-94.

Hughes JM, Schmidt DJ, Finn DS. Genes in streams: using DNA to understand the movement of freshwater fauna and their riverine habitat. BioScience. 2009; 59(7):573-83.

Josephson DC, Robinson JM, Weidel BC, Kraft CE. Long-term retention and visibility of visible implant elastomer tags in brook trout. N Am J Fish Manag. 2008; 28(6):1758-61.

Kadry VO, Barreto RE. Environmental enrichment reduces aggression of pearl cichlid, Geophagus brasiliensis, during resident-intruder interactions. Neotrop Ichthyol. 2010; $8(2): 329-32$.
Knaepkens G, Baekelandt K, Eens M. Assessment of the movement behaviour of the bullhead (Cottus gobio), an endangered european freshwater fish. Anim Biol. 2005; 55(3):219-26.

Lobón-Cerviá J. Dinamica de poblaciones de peces en rios: pesca eléctrica y métodos de capturas sucessivas en la estima de abundancias. Monografias del Museo Nacional de Ciencias Naturales. Madrid: Centro de Investigaciones de Agua; 1991.

Loebmann D, Vieira JP. Composição e abundância dos peixes do Parque Nacional da Lagoa do Peixe, Rio Grande do Sul, Brasil e comentários sobre a fauna acompanhante de crustáceos decápodos. Atlântica. 2005; 27(2):131-37.

Marcucci KMI, Orsi ML, Shibatta OA. Abundance and reproductive aspects of Loricarichthys platymetopon (Siluriformes, Loricariidae) in four sections of the Capivara Reservoir, river Paranapanema. Iheringia, Ser Zool. 2005; 95(2):197-203.

Martin-Smith KM, Laird LM, Bullough L, Lewis MG. Mechanisms of maintenance of tropical freshwater fish communities in the face of disturbance. Philos Trans R Soc Lond B. 1999; 354(1391):1803-10.

Mazzoni R, Caramaschi EP. Size structure, sex ratio and onset of sexual maturity of two species of Hypostomus. J Fish Biol. 1995; 47(5):841-49.

Mazzoni R, Fenerich-Verani N, Caramaschi EP. Electrofishing as a sampling technique for coastal stream fish populations and communities in the southeast of Brazil. Rev Bras Biol. 2000; 60(2):205-16.

Mazzoni R, Fenerich-Verani N, Caramaschi EP, Iglesias-Rios R. Stream-dwelling fish communities from an Atlantic Rain Forest drainage. Brazil Arch Biol Technol. 2006; 49(2):249-56.

Mazzoni R, Iglesias-Rios R. Environmentally related life history variations in Geophagus brasiliensis. J Fish Biol. 2002; 61(6):1606-18.

Mazzoni R, Iglesias-Rios R. Movement patterns of streamdwelling fishes from Mata Atlântica, southeast Brazil. Rev Biol Trop. 2012; 60(4):1837-46.

Mazzoni R, Lobón-Cerviá J. Longitudinal structure, density and production rates of a neotropical stream fish assemblage: the river Ubatiba in the Serra do Mar, southeast Brazil. Ecography. 2000; 23(5):588-602.

Mazzoni R, Mendonça RS, Caramaschi EP. Reproductive biology Astyanax janeiroensis (Osteichthyes, Characidae) from the Ubatiba river, Maricá, RJ, Brazil. Brazil J Biol. 2005; 65(4):643-49.

Mazzoni R, Silva RC, Pinto MP. Invasion and colonisation of a tropical stream by an exotic loricariid fish: indices of gradual displacement of the native common pleco (Hypostomus punctatus) by the red fin dwarf pleco (Parotocinclus maculicauda) over fifteen years. PLoS ONE. 2015; 10(10):e0139968 [12p.].

Minckley WL, Marsh PC. Inland fishes of the greater southwest: chronicle of a vanishing biota. Tucson (AZ): The University of Arizona Press. 2009.

Nathan R. An emerging movement ecology paradigm. Proc Natl Acad Sci USA. 2008; 105(49):19050-51. 
Nathan R, Getz WM, Revilla E, Holyoak M, Kadmon R, Saltz D, Smouse PE. A movement ecology paradigm for unifying organismal movement research. Proc Natl Acad Sci USA. 2008; 105(49):19052-59.

Neiff JJ. Ideas para la interpretación ecológica del Paraná. Interciencia. 1990; 15(6):424-41.

Paraguassú AR, Alves DR, Luquel JL. Metazoários parasitos do acará Geophagus brasiliensis (Quoy; Gaimard, 1824) (Osteichthyes: Cichlidae) do Reservatório de Lajes, Estado do Rio de Janeiro, Brasil. Rev Brasil Parasitol Vet. 2005; 14(1):35-39.

Pesoa NA, Schulz UH. Diel and seasonal movements of grumatã Prochilodus lineatus (Valenciennes 1836) (Characiformes: Prochilodontidae) in the Sinos river, southern Brazil. Braz J Biol. 2010; 70(4 Suppl.):1169-77.

Petty JT, Grossman GD. Restricted movement by mottled sculpin (Pisces: Cottidae) in a southern Appalachian stream. Freshwater Biol. 2004; 49(5):631-45.

Porto LM, McLaughlin RL, Noakes DLG. Low-head barrier dams restrict the movements of fishes in two lake Ontario streams. N Am J Fish Manag. 1999; 19(4):1028-36.

Quinn TP, Myers KW. Anadromy and the marine migrations of Pacific salmon and trout: Rounsefell revisited. Rev Fish Biol Fisher. 2004; 14(4):421-42.

Riley SC, Fausch KD, Gowan C. Movement of brook trout (Salvelinus fontinalis) in four small subalpine streams in northern Colorado. Ecol Freshw Fish. 1992; 1(2):112-22.

Roberts JH, Angermeier PL. Spatiotemporal variability of stream habitat and movement of three species of fish. Oecologia. 2007; 151(3):417-30.

Roberts JH, Rosenberger AE, Albanese BW, Angermeier PL. Movement patterns of endangered Roanoke logperch (Percina rex). Ecol Freshw Fish. 2008; 17(3):374-81.

Rodríguez MA. Restricted movement in stream fish: the paradigm is incomplete, not lost. Ecology. 2002; 83(1):1-13.

Romão F, Quaresma AL, Branco P, Santos JM, Amaral S, Ferreira MT, Katopodis C, Pinheiro AN. Passage performance of two cyprinids with different ecological traits in a fishway with distinct vertical slot configurations. Ecol Eng. 2017; 105:180-88.

Schlosser IJ. Stream fish ecology: a landscape perspective. BioScience. 1991; 41(10):704-12.
Schlosser IJ. Critical landscape attributes that influence fish population dynamics in headwater streams. Hydrobiologia. 1995; 303(1-3):71-81.

Schulz UH, Leal ME. Effects of stocking density on dispersal behavior of brazilian freshwater dourado (Salminus brasiliensis) in a subtropical river headwater. Neotrop Ichthyol. 2012; 10(2):409-15.

Skalski GT, Gilliam JF. Modeling diffusive spread in a heterogeneous population: a movement study with stream fish. Ecology. 2000; 81(6):1685-1700.

Smithson EB, Johnston CE. Movement patterns of stream fishes in a Ouachita Highlands stream: an examination of the restricted movement paradigm. Trans Am Fish Soc. 1999; 128(5):847-53.

Soula M, Navarro A, Hildebrandt S, Zamorano MJ, Roo J, Hernandez-Cruz CM, Afonso JM. Evaluation of VIE (Visible Implant Elastomer) and PIT (Passive Integrated Transponder) physical tagging systems for the identification of red porgy fingerlings (Pagrus pagrus). Aquac Int. 2012; 20(3):571-83.

Tejerina-Garro FL, Mérona B. Flow seasonality and fish assemblage in a tropical river, French Guiana, South America. Neotrop Ichthyol. 2010; 8(1):145-54.

Walsh MG, Winkelman DL. Anchor and visible implant elastomer tag retention by hatchery rainbow trout stocked into an Ozark stream. N Am J Fish Manag. 2004; 24(4):1435-39.

Winemiller KO, Jepsen DB. Effects of seasonality and fish movement on tropical river food webs. J Fish Biol. 1998; 53(sA):267-96.

Young MK. Generation-scale movement patterns of cutthroat trout (Oncorhynchus clarkii pleuriticus) in a stream network. Can J Fish Aquat Sci. 2011; 68(5):941-51.

Young MK. Mobility of brown trout in south-central Wyoming streams. Can J Zool. 1994; 72(12):2078-83.

Zippin C. The removal method of population estimation. J Wildl Manag. 1958; 2(1):82-90. 
